\title{
Hubungan Komunikasi Efektif dengan Kepuasan Pendonor Darah dalam Pelayanan Seleksi Donor di Unit Transfusi Darah Palang Merah Indonesia Kota Yogyakarta
}

\author{
The Correlation of Effective Communication and Blood Donor Satisfaction \\ in Donor Selection Service at Blood Transfusion Unit Indonesia Red Cross \\ Yogyakarta City
}

Yuli Astuti ${ }^{1}$, Dyah Artini ${ }^{1}$

1) Prodi Teknologi Bank Darah (D-3), Fakultas Kesehatan Univesitas Jendral Achmad Yani Yogyakarta, Jl. Brawijaya, Ringroad Barat, Ambarketawang, Gamping, Sleman, Daerah Istimewa Yogyakarta 55294, Indonesia

Korespondensi: astuti_yuli35@yahoo.co.id

Submitted: 20 September 2019, Revised: 6 Desember 2019, Accepted: 18 Desember 2019

https://doi.org/10.22435/jpppk.v3i3.2737

\begin{abstract}
Abstrak
Berdasarkan standar organisasi kesehatan dunia WHO, jumlah kebutuhan minimal darah di Indonesia sekitar 5,1 juta kantong darah per tahun ( $2 \%$ jumlah penduduk Indonesia). Ketersediaan darah tergantung pada donor darah sukarela. Kepuasan pendonor dapat meningkatkan keinginan untuk mendonor kembali. Hal ini dapat didukung oleh adanya komunikasi efektif. Penelitian ini bertujuan untuk mengetahui hubungan komunikasi efektif dilihat dari aspek REACH (respect, emphaty, audible, clarify, humble) dengan kepuasan pendonor darah dalam pelayanan seleksi donor di UTD PMI Kota Yogyakarta. Penelitian ini menggunakan desain cross sectional dengan metode accidental sampling. Kuesioner dibagikan kepada 30 responden terpilih yang melakukan donor darah di UTD PMI Kota Yogyakarta. Uji statistik yang digunakan adalah Somers dan Gamma dengan aplikasi SPSS IBM 23. Hampir seluruh aspek REACH dilaksanakan dengan frekuensi 'kadang-kadang' atau 'selalu'. Sebagian besar responden merasa cukup puas (50\%) dan puas (30\%). Ada hubungan antara komunikasi efektif dengan kepuasan pendonor darah yang signifikan secara statistik $(p<0,05)$.
\end{abstract}

Kata kunci: Komunikasi efektif, kepuasan, donor darah, seleksi donor

\begin{abstract}
Based on World Health Organization (WHO) standards, the minimum blood requirement in Indonesia is around 5.1 million blood bags per year (2\% of the population of Indonesia). The availability of blood depends on voluntary blood donation. Donor satisfaction can increase the desire to donate again. It could be related to effective communication. This study aimed to determine the correlation of effective communication measured by REACH (respect, empathy, audible, clarify, humble) aspects and the satisfaction of blood donors in donor selection services at UTD PMI Yogyakarta City. This study used a cross-sectional design with accidental sampling method. Questionnaires were distributed to 30 respondents selected who did blood donation at UTD PMI Yogyakarta City. Data collected were analyzed with Somers and Gamma test using the IBM SPSS 23 application. Most of the REACH aspects were conducted frequently. Half of the respondents were quite satisfied and about $30 \%$ were fully satisfied. There was significantly correlation between effective communication and blood donors satisfaction $(p<0.05)$.
\end{abstract}

Keywords: Effective communication, satisfaction, blood donors, donor selection 


\section{Pendahuluan}

Pelayanan transfusi merupakan pelayanan darah dengan menggunakan darah manusia dengan tujuan tidak komersial. Transfusi darah merupakan salah satu upaya pengobatan yang dapat menyembuhkan dan menyelamatkan nyawa manusia sehingga dibutuhkan ketersediaan komponen darah yang cukup, aman dan mudah diakses oleh masyarakat. ${ }^{1}$

Berdasarkan standar organisasi kesehatan dunia WHO, jumlah kebutuhan minimal darah di Indonesia sekitar 5,1 juta kantong darah pertahun, sedangkan produksi darah dan komponennya saat ini sebanyak 4,1 juta kantong dari 3,4 juta donasi. Dari jumlah darah yang tersedia, $90 \%$ di antaranya berasal dari donasi sukarela. Donor darah merupakan salah satu langkah penting dalam menyelamatkan nyawa manusia yang digunakan untuk pasien yang melakukan operasi, proses transfusi atau kondisi klinis yang lain yang menyebabkan seseorang kehilangan darah. ${ }^{2}$

Menurut PMK 91 tahun 2015, unit pelayanan darah di Indonesia yang menyelenggarakan pelayanan donor darah diselenggarakan di Unit Transfusi Darah Palang Merah Indonesia (UTD PMI), dan Unit Transfusi Rumah Sakit (UTDRS). Pelayanan donor darah dimulai dengan pelayanan awal yaitu, pelayanan seleksi pendonor darah. Pelayanan seleksi pendonor darah merupakan skrining awal untuk memastikan bahwa pendonor darah sukarela dinyatakan dalam kondisi sehat dan digunakan untuk mengidentifikasi faktor risiko yang dapat memengaruhi keamanan darah donor. ${ }^{1}$

Ketersediaan darah dalam pelayanan transfusi darah dipengaruhi oleh kesediaan pendonor darah sukarela yang dinyatakan sehat dan lolos pada pemeriksaan seleksi donor darah. Darah yang didonasikan oleh pendonor harus dipastikan terbebas dari penyakit menular. ${ }^{3}$

Komunikasi efektif pada pelayanan seleksi donor memegang peranan penting dikarenakan pada tahap ini seorang petugas pelayanan darah harus mampu menggali informasi diri dan informasi medis terkait syarat sehat sebagai seorang pendonor darah. Pada tahap seleksi selain menggali informasi pendonor, pada pelayanan ini terjadi pemberian informasi dan edukasi tentang syarat donor darah yang sehat. Komunikasi efektif yang digunakan adalah komunikasi interpersonal kepada calon donor, komunikasi ini dapat membina hubungan yang baik antara petugas dan calon donor, yang membuat calon donor nyaman saat petugas melakukan tindakan donor darah. ${ }^{4}$

Pelayanan yang baik dalam pelayanan donor darah dilakukan oleh petugas yang dinyatakan kompeten. Hal ini bertujuan agar pendonor darah bersedia menjadi donor darah sukarela yang rutin melakukan donor darah, sehingga kebutuhan darah di Indoensia terpenuhi. Strategi yang dapat digunakan oleh petugas adalah melakukan pelayanan yang aman dan meminimalisir risiko. Pelayanan yang memuaskan akan meningkatkan ketersediaan donor darah sukarela. ${ }^{5}$

Komunikasi efektif memegang peranan penting dalam kepuasan pelayanan kesehatan di dalam komunikasi efektif bukan hanya memberikan informasi tetapi di dalamnya juga terdapat penyampaian informasi mengenai perasaan dan sikap dari orang yang menerima informasi dan pemberi informasi. Aspek dalam komunikasi efektif terdiri dari aspek REACH (respect, emphaty, audible, clarity, dan humble) ${ }^{6}$

Berdasarkan penelitian yang dilakukan oleh (Chandra Swastika dkk. 2018) menyebutkan bahwa dalam pelayanan kesehatan terdapat hubungan yang kuat antara komunikasi efektif dengan kepuasan klien. Komunikasi efektif pada pelayanan kesehatan dapat meningkatkan kepercayaan pada petugas dan dapat membantu proses terapi penyembuhan yang diberikan. $^{7}$

Kepuasan pendonor setelah melakukan donor darah dapat meningkatkan ketersediaan pendonor darah sukarela. Hal ini didukung dengan petugas pelayanan darah yang profesional. Pelayanan yang berkualitas untuk meningkatkan donor darah sukarela. ${ }^{8}$

Pemberian komunikasi efektif petugas kesehatan dipengaruhi beberapa faktor determinan yaitu lama bekerja, intensitas interaksi dengan klien, pelatihan dan pengalaman selama bekerja. Pelatihan kepada petugas kesehatan dapat meningkatkan keterampilan petugas dalam memberikan komunikasi efektif. Komunikasi efektif dapat digunakan petugas untuk mencari informasi tentang kesehatan klien dan menentukan promosi dan edukasi yang tepat kepada klien tentang kesehatan. 
Hal ini, dapat meningkatkan kepuasan klien terhadap petugas kesehatan. ${ }^{9,10}$

Unit Transfusi Darah (UTD) PMI Kota Yogyakarta merupakan salah satu unit pelayanan darah yang menyediakan layanan seleksi donor pada calon pendonor darah. UTD PMI Kota Yogyakarta berdasarkan data tahun 2017 tercatat ada 43.669 pendonor yang melakukan donor darah. Berdasarkan angka tersebut kebutuhan darah di UTD PMI Kota Yogyakarta terpenuhi.

Berdasarkan studi pendahuluan yang dilakukan peneliti, di UTD PMI Kota Yogyakarta terdapat 25 petugas pelayanan darah yang melakukan pelayanan di unit seleksi pendonor darah. Petugas pelayanan darah yang berjumlah 25 orang dinyatakan sudah kompeten dengan adanya kepemilikan Surat Tanda Registrasi (STR).

Maka dari itu peneliti tertarik untuk melakukan penelitian tentang pengaruh pelaksanaan komunikasi efektif terhadap kepuasan calon pendonor darah dalam seleksi donor di UTD PMI Kota Yogyakarta. Calon pendonor darah yang dilakukan penelitian adalah calon penonor darah baru (pertama kali) dan calon pendonor darah rutin.

Masalah penelitian ini adalah pengaruh pelaksanaan komunikasi efektif yang dilakukan oleh petugas terhadap kepuasan pendonor darah di laboratorium seleksi donor UTD PMI Kota Yogyakarta. Tujuan penelitian ini adalah untuk mengetahui pengaruh komunikasi efektif berdasarkan aspek komunikasi efektif (respect, emphaty, audible, clarity, dan humble) terhadap kepuasan pendonor darah di laboratorium seleksi donor UTD PMI Kota Yogyakarta.

\section{Metode}

Subjek penelitian ini adalah calon pendonor darah yang datang pada waktu pengambilan data. Teknik pengambilan sampel dalam penelitian ini menggunakan accidental sampling, yaitu dengan mengambil kasus atau responden yang kebetulan ada atau tersedia. Jumlah sampel pada penelitian sejumlah 30 pendonor, jumlah sampel minimal untuk penelitian. ${ }^{11}$

Pada penelitian ini selain menggunakan teknik observasional juga melakukan pembagian kuisioner, kuisioner berisi pertanyaan-pertanyaan yang berkaitan dengan penerapan komunikasi efektif dan kepuasan calon donor. Kuisioner diisi dengan skala likert skala 1-4 kepada pendonor darah yang diberikan pelayanan di seleksi pendonor darah untuk menilai pelaksanaan komunikasi efektif yang dilakukan oleh petugas. Kuisioner juga diberikan kepada pendonor darah untuk menilai kepuasan pendonor darah setelah mendapatkan pelayanan tentang pelaksanaan penggunaan komunikasi efektif yang dilakukan oleh petugas.

Pengambilan data dilaksanakan di Bulan Agustus-September di Laboratorium Seleksi Pendonor Darah di UTD PMI Kota Yogyakarta. Analisis data dalam penelitian ini dikarenakan skala kedua variabel yang dilakukan pengukuran merupakan skala kategorik (ordinal dengan ordinal) dengan menggunakan uji korelatif Sommers dan Gamma. ${ }^{12}$

Penelitian ini dengan menggunakan responden manusia, dan sudah mendapatkan persetujuan etik dari Komite Etik Fakultas Kesehatan Universitas Jenderal Achmad Yani Yogyakarta. Pada saat pengambilan data, peneliti meminta persetujuan dengan lembar informed concent, responden mengisi setelah mendapatkan penjelasan dari peneliti.

\section{Hasil}

\section{Karakteristik Responden}

Hasil penelitian berdasarkan karakteristik responden dilihat dari jenis kelamin, usia, tingkat pendidikan dan pekerjaan. Untuk karakteristik responden dapat dilihat pada Tabel 1.

Berdasarkan Tabel 1 dapat dilihat karakteristik responden pendonor darah terbanyak adalah berjenis kelamin laki-laki (73,33\%), usia 20-30 tahun (30\%), pendidikan sarjana dan diploma $(56,67 \%)$, dan pekerjaan swasta $(46,67 \%)$.

\section{Pelaksanaan Komunikasi Efektif}

Berdasarkan hasil yang diolah dari kuisioner untuk hasil pelaksanaan komunikasi efektif dapat dilihat pada Tabel 2.

Berdasarkan Tabel 2 tentang distribusi frekuensi pelaksanaan komunikasi efektif didapatkan hasil, presentase terbesar pelaksanaan komunikasi efektif komponen respect adalah kadang-kadang dilakukan (50\%), komponen 
Tabel 1. Distribusi Frekuensi Karakteristik Pendonor Darah di UTD PMI Kota Yogyakarta

\begin{tabular}{lcc}
\hline \multicolumn{1}{c}{ Karakteristik } & $\begin{array}{c}\text { Frekuensi } \\
(\mathbf{N}=\mathbf{3 0})\end{array}$ & $\begin{array}{c}\text { Persentase } \\
\text { (\%) }\end{array}$ \\
\hline Jenis kelamin & & \\
Laki-laki & 22 & 73,33 \\
Perempuan & 8 & 26,67 \\
Usia (tahun) & & \\
20-30 & 9 & 30 \\
31-40 & 6 & 20 \\
41-50 & 7 & 23,33 \\
51-60 & 8 & 26,67 \\
Tingkat Pendidikan & & \\
Tidak sekolah & 0 & 0 \\
SD & 0 & 0 \\
SMP & 0 & 0 \\
SMA & 13 & 43,33 \\
Sarjana/Diploma & 17 & 56,67 \\
Pekerjaan & & \\
Tidak bekerja & 5 & 16,67 \\
Swasta & 14 & 46,67 \\
Wiraswasta & 9 & 30 \\
PNS & 1 & 3,33 \\
Pensiunan & 1 & 3,33 \\
\hline
\end{tabular}

emphaty sering dilakukan (53,33\%), audible selalu dilakukan (53,33\%), komponen clarity sering dilakukan $(46,67 \%)$ dan komponen humble sering dilakukan $(60 \%)$.

\section{Kepuasan pendonor}

Berdasarkan hasil yang diolah dari kuisioner untuk hasil kepuasan pendonor dapat dilihat pada Tabel 3.

Berdasarkan Tabel 3 distribusi frekuensi tentang kepuasan pendonor didapatkan cukup puas dengan pelayanan petugas terkait pelaksanaan komunikasi efektif yang dilakukan petugas (50\%).

\section{Pengaruh Komunikasi Efektif dan Kepuasan Pendonor}

Pada penelitian ini menggunakan dua analisis, setelah selesai dilakukan analisis univariat dengan distribusi frekuensi dari masing-masing

\section{Tabel 2. Distribusi Frekuensi Pelaksanaan} Komunikasi Efektif

\begin{tabular}{|c|c|c|}
\hline $\begin{array}{c}\text { Pelaksanaan Komunikasi } \\
\text { Efektif }\end{array}$ & $\begin{array}{l}\text { Frekuensi } \\
(\mathrm{N}=\mathbf{3 0})\end{array}$ & $\begin{array}{l}\text { Persentase } \\
\quad(\%)\end{array}$ \\
\hline \multicolumn{3}{|l|}{ Respect } \\
\hline Tidak pernah dilakukan & 4 & 13,33 \\
\hline Kadang-kadang dilakukan & 15 & 50 \\
\hline Sering dilakukan & 10 & 33,33 \\
\hline Selalu dilakukan & 1 & 3,34 \\
\hline \multicolumn{3}{|l|}{ Emphaty } \\
\hline Tidak pernah dilakukan & 0 & 0 \\
\hline Kadang-kadang dilakukan & 6 & 20 \\
\hline Sering dilakukan & 16 & 53,33 \\
\hline Selalu dilakukan & 8 & 26,67 \\
\hline \multicolumn{3}{|l|}{ Audible } \\
\hline Tidak pernah dilakukan & 0 & 0 \\
\hline Kadang-kadang dilakukan & 3 & 10 \\
\hline Sering dilakukan & 11 & 36,67 \\
\hline Selalu dilakukan & 16 & 53,33 \\
\hline \multicolumn{3}{|l|}{ Clarity } \\
\hline Tidak pernah dilakukan & 0 & 0 \\
\hline Kadang-kadang dilakukan & 6 & 20 \\
\hline Sering dilakukan & 14 & 46,67 \\
\hline Selalu dilakukan & 10 & 33,33 \\
\hline \multicolumn{3}{|l|}{ Humble } \\
\hline Tidak pernah dilakukan & 0 & 0 \\
\hline Kadang-kadang dilakukan & 5 & 16,67 \\
\hline Sering dilakukan & 18 & 60 \\
\hline Selalu dilakukan & 7 & 23,33 \\
\hline
\end{tabular}

Tabel 3. Distribusi Frekuensi Kepuasan Pendonor

\begin{tabular}{llcc}
\hline No & $\begin{array}{r}\text { Kepuasan } \\
\text { Pendonor }\end{array}$ & $\begin{array}{c}\text { Frekuensi } \\
(\mathbf{N = 3 0 )}\end{array}$ & $\begin{array}{c}\text { Persentase } \\
(\mathbf{\%})\end{array}$ \\
\hline 1. & Tidak puas & 0 & 0 \\
2. & Kurang Puas & 6 & 20 \\
3. & Cukup Puas & 15 & 50 \\
4. & Puas & 9 & 30 \\
& Total & 30 & 100 \\
\hline
\end{tabular}


Tabel 4 Pengaruh Komunikasi Efektif terhadap Kepuasan Pendonor di UTD PMI Kota Yogyakarta

\begin{tabular}{|c|c|c|c|c|c|c|}
\hline \multirow{2}{*}{$\begin{array}{c}\text { Pelaksanaan komunikasi } \\
\text { efektif }\end{array}$} & \multicolumn{4}{|c|}{ Kepuasan Pendonor darah } & \multirow[t]{2}{*}{ Total } & \multirow{2}{*}{$\begin{array}{c}\text { P value } \\
\text { (Approx sig) }\end{array}$} \\
\hline & Tidak Puas & Kurang puas & Cukup Puas & Puas & & \\
\hline \multicolumn{7}{|l|}{ Respect } \\
\hline Tidak pernah dilakukan & 0 & 0 & 0 & 0 & 0 & 0,001 \\
\hline Kadang dilakukan & 0 & 5 & 4 & 2 & 11 & \\
\hline Sering dilakukan & 0 & 4 & 3 & 3 & 10 & \\
\hline Selalu dilakukan & 0 & 3 & 2 & 4 & 9 & \\
\hline \multicolumn{7}{|l|}{ Emphaty } \\
\hline Tidak pernah dilakukan & 0 & 0 & 0 & 0 & 0 & 0,001 \\
\hline Kadang dilakukan & 0 & 5 & 1 & 0 & 6 & \\
\hline Sering dilakukan & 0 & 2 & 9 & 5 & 16 & \\
\hline Selalu dilakukan & 0 & 0 & 5 & 3 & 8 & \\
\hline \multicolumn{7}{|l|}{ Audible } \\
\hline Tidak pernah dilakukan & 0 & 0 & 0 & 0 & 0 & 0,000 \\
\hline Kadang dilakukan & 0 & 3 & 0 & 0 & 3 & \\
\hline Sering dilakukan & 0 & 4 & 5 & 2 & 11 & \\
\hline Selalu dilakukan & 0 & 0 & 10 & 6 & 16 & \\
\hline \multicolumn{7}{|l|}{ Clarity } \\
\hline Tidak pernah dilakukan & 0 & 0 & 0 & 0 & 0 & 0,000 \\
\hline Kadang dilakukan & 0 & 4 & 2 & 0 & 6 & \\
\hline Sering dilakukan & 0 & 3 & 8 & 3 & 14 & \\
\hline Selalu dilakukan & 0 & 0 & 5 & 5 & 10 & \\
\hline \multicolumn{7}{|l|}{ Humble } \\
\hline Tidak pernah dilakukan & 0 & 0 & 0 & 0 & 0 & 0,009 \\
\hline Kadang dilakukan & 0 & 3 & 1 & 1 & 5 & \\
\hline Sering dilakukan & 0 & 4 & 9 & 5 & 18 & \\
\hline Selalu dilakukan & 0 & 0 & 5 & 2 & 7 & \\
\hline Total responden $(\mathbf{N})$ & & & & & 30 & \\
\hline
\end{tabular}

variabel yang diteliti, selanjutnya dilakukan analisis bivariate dengan menggunakan bantuan SPSS IBM 23 pengukuran merupakan skala kategorik (ordinal dengan ordinal) dengan menggunakan uji korelatif Sommers dan Gamma. Hasil analisis bivariate dengan menggunakan SPSS, untuk hasil analisa dapat dilihat pada Tabel 4 .

Berdasarkan hasil Tabel 4 dapat dilihat untuk hasil analisis nilai $P$ dari masing-masing komponen pelaksanaan komunikasi efektif (respect, emphaty, audible, clarity, dan humble) untuk nilai $P$ dari masing-masing komponen komunikasi efektif adalah $P<0,05$, terdapat pengaruh antara pelaksanaan komunikasi efektif terhadap kepuasan pendonor darah.

\section{Pembahasan}

Berdasarkan hasil analisis tentang pengaruh komunikasi efektif yang terdiri dari lima komponen penilaian yaitu respect, emphaty, audible, clarity, dan humble terhadap kepuasan pendonor darah di pelayanan seleksi donor yang sudah dilakukan dengan menggunakan SPSS IBM 21 dengan uji statistik Sommers dan Gamma didapatkan hasil nilai $P<0,05$. Hal ini secara statistik dapat dikatakan mempunyai pengaruh yang bermakna pada 
pelaksanaan komunikasi efektif terhadap kepuasan pendonor darah di pelayanan seleksi donor. ${ }^{13}$

Berdasarkan penelitian serupa yang dilakukan oleh (Norouzinia Roohangis, dkk. 2016) komunikasi efektif merupakan komponen penting dalam memberikan pelayanan kesehatan, menggunakan komunikasi efektif dapat menurunkan rasa cemas, rasa bersalah dan rasa sakit dari gejala sebuah penyakit yang dirasakan oleh klien, dan hal ini berdampak pada persepsi klien tentang pelayanan kesehatan yang dilakukan oleh petugas. Hal ini dapat meningkatkan kepuasan klien dalam menerima layanan kesehatan.

Kepuasan klien dapat diwujudkan dengan pelayanan bermutu yang dilakukan oleh petugas kesehatan. Dalam dimensi mutu pelayanan kesehatan, dimensi informasi merupakan merupakan salah satu komponen yang harus dipenuhi agar pelayanan dikatakan baik dan bermutu. Dimensi informasi ini mencakup pemberian informasi yang jelas tentang apa, siapa, kapan, di mana dan bagaimana layanan kesehatan itu akan dan atau telah dilaksanakan. Dimensi informasi dapat terwujud jika petugas dalam memberikan pelayanan kesehatan menerapkan komunikasi efektif. ${ }^{14}$

Kepuasan dalam melakukan donor darah berhubungan erat dengan motivasi seseorang untuk melakukan donor darah lagi. Kepuasan donor ini jika antara harapan dan keinginan sesuai. Motivasi positif yang dihasilkan oleh seorang pendonor, dapat memberikan efek jangka panjang untuk unit transfusi darah dalam memberikan pelayanan darah, begitupun sebaliknya motivasi negatif seorang pendonor karena layanan donor darah yang tidak puas akan mengakibatkan seseorang tidak mau untuk melakukan donor darah lagi, hal ini bisa berdampak terhadap kesediaan darah. ${ }^{16}$

Penerapan komunikasi efektif dapat meningkatkan persepsi klien tentang pelayanan kesehatan yang dilakukan oleh petugas menjadi sebuah pengalaman yang positif. Hal ini berdampak pada sesuatu yang positif, yaitu klien akan melakukan kunjungan ulang untuk menggunakan pelayanan kesehatan. ${ }^{15}$

Komunikasi yang tidak efektif seorang petugas kepada klien dapat mengakibatkan kesalahpahaman, hal ini bisa memicu suatu perdebatan atau konflik. Beberapa hal yang dapat memengaruhi seseorang untuk dapat melakukan komunikasi efektif adalah hambatan bahasa, tingkat pendidikan, dan latar belakang budaya yang beraneka ragam. Komunikasi dalam hal pelayanan darah adalah dua tipe pelayanan yang diberikan, yaitu tentang rekrutmen pendonor darah dan layanan pengguna darah untuk transfusi. Dalam hal ini perlu komunikasi yang efektif petugas donor darah untuk menjelaskan secara teknis maupun non teknis. ${ }^{17}$

Petugas dalam pelayanan donor darah akan bertemu dengan pendonor darah yang baru pertama kali donor, dan pendonor darah yang sudah pernah melakukan donor darah, tentunya komunikasi efektif berperan sangat penting dalam hal ini, kaitannya adalah untuk memotivasi seseorang untuk melakukan donor darah secara rutin. Komunikasi yang dilakukan untuk pengguna darah (pasien dan tenaga kesehatan lain yang terlibat) perlu juga dilakukan edukasi yang berkaitan tentang penggunaan darah yang aman. ${ }^{17}$

Dalam kaitannya pelayanan darah khususnya pelayanan seleksi donor pada pendonor darah sukarela hal ini merupakan suatu hal yang positif jika seorang pendonor darah sukarela bersedia melakukan kunjungan ulang untuk melakukan donor darah. Hal tersebut dapat memenuhi ketersediaan darah dan keberadaan donor darah lestari.

Kepuasaan pendonor darah salah satunya adalah calon pendonor mendapatkan informasi yang baik tentang donor darah dan kesehatannya. Salah satu cara untuk mendapatkan informasi yang baik pada calon pendonor diperlukan adanya komunikasi efektif. ${ }^{18}$

Seseorang yang sudah mendonorkan darahnya dan jika merasa puas, hal ini dapat mendukung tentang penyebaran informasi dari mulut ke mulut di masyarakat tentang donor darah. Sehingga masyarakat yang belum melakukan donor dapat mendonorkan darahnya. Calon donor darah yang baru akan meningkat sehingga ketersediaan darah terpenuhi. ${ }^{17}$

\section{Kesimpulan}

Kesimpulan penelitian ini adalah persentase terbesar pelaksanaan komunikasi efektif komponen respect adalah kadang-kadang dilakukan (50\%), komponen emphaty $(53,33 \%)$, komponen audible selalu dilakukan (53,33\%), komponen clarity sering 
dilakukan (46,67\%), dan komponen humble sering dilakukan $(60 \%)$, pendonor cukup puas dengan pelayanan komunikasi efektif yang dilakukan petugas $(50 \%)$, dan pengaruh pelaksanaan komunikasi efektif petugas terhadap kepuasaan pendonor darah didapatkan hasil nilai $\mathrm{P}<0,05$ yang secara statistik dikatakan mempunyai pengaruh secara bermakna.

\section{Saran}

Saran dari penelitian ini diharapkan kepada petugas pelayanan darah dapat meningkatkan pelaksaaan komunikasi efektif dengan lima komponen respect, emphaty, audible, clarity, dan humble dalam pelayanan darah, khususnya pada pelayanan di seleksi pendonor darah. Bagi pendonor darah sukarela diharapkan secara sadar untuk berdonor darah secara rutin. Penelitian ini masih belum sempurna dan terdapat kekurangan, untuk peneliti lanjutan, dapat meneliti faktor lain yang memengaruhi kepuasan pendonor darah selain komunikasi efektif yang dilakukan oleh petugas.

\section{Ucapan Terima Kasih}

Terima kasih kepada Dekan dan Ketua PPPM, dan seluruh Tim Dosen Prodi Teknologi Bank Darah(D-3)Fakultas Kesehatan Universitas Jenderal Achmad Yani Yogyakarta yang telah memberikan bantuan dalam penelitian ini. Kemudian terima kasih kepada Kepala Unit Transfusi Darah dan staf UTD PMI Kota Yogyakarta yang telah memberikan izin lokasi untuk dapat digunakan penelitian.

\section{Daftar Rujukan}

1. Kementerian Kesehatan RI. Peraturan Menteri Kesehatan No.91 Tahun 2015 Tentang Standar Pelayanan Transfusi darah. [Diakses pada tanggal 11 Agustus 2019], tersedia di https:// www.persi.or.id/images/regulasi/permenkes/ pmk912015.pdf

2. Al-Hindi, A., Khabour, O., Alzoubi, K., \& AlSawalha, N. A. (2018). The attitude of blood donors towards the use of their samples and information in biomedical research. Journal of Blood Medicine, Volume 9, 145-151. [Diakses pada tanggal 11 Agustus 2019] tersedia di https://pubmed.ncbi.nlm.nih.gov/30288135/

3. Republik Indonesia. Undang-Undang Republik
Indonesia No 36 Tahun 2009 Tentang Kesehatan. [ Diakses pada tanggal 20 Agustus 2019], p 39-40 tersedia di https://jdih.kemenkeu.go.id/ fulltext/2009/36TAHUN2009UU.htm

4. Abril EA. 2016. Explaining Voluntary Blood Donation From a Communication Perspective. Cuadernos. 38. 53-69. 10.7764/cdi.38.697. [Diakses pada tanggal 13 Agustus 2019] tersedia di https://www.researchgate.net/ publication/316669621_Explaining_Voluntary_ Blood_Donation_from_a_Communication_ Perspective

5. S Uma, R Arun, P Arumugam. The Knowledge, Attitude and Practice Towards Blood Donation Among Voluntary Blood Donors in Chennai, India. J Clin Diagn Res. 2013: 7(6): 10431046. [Diakses pada tanggal 14 Agustus 2019], tersedia di https://www.ncbi.nlm.nih.gov/pmc/ articles/PMC3708194/

6. Herlambang Susatyo. Customer Service Rumah Sakit dan Jasa Kesehatan. Yogyakarta. Gosyen Publishing.2018

7. Chanda Swastika, Mohammadnezhad Masoud, Ward Paul. 2018. Trust and Communication in a Doctor Patient Relationship: A Literature Review. Journal of Healthcare Communications ISSN 2472-1654. Vol.3 No.3:36. [Diakses pada tanggal 28 Agustus 2019], tersedia di https:// healthcare-communications.imedpub.com/ trust-and-communication-in-a-doctorpatientrelationship-a-literature-review.pdf

8. Giacomino; et al. (2010). Strategies to increase recruitment of voluntary and habitual blood donors. Acta Paul Enferm 2010;23(1):65-72. [Diakses pada tanggal 28 Agustus 2019], tersedia di http://citeseerx.ist.psu.edu/viewdoc/ download?doi=10.1.1.930.4527\&rep=rep1\&type $=$ pdf

9. Shing G. 2011. Healthcare service delivery and customer satisfaction: Insight from government hospitals in Fiji. International Journal of Services Economics and Management 3: 323335. [Diakses pada tanggal 28 Agustus 2019], tersedia di https://ideas.repec.org/a/ids/injsem/ v3y2011i3p323-335.html

10. Biglu Mohammad Husein. Nateq Farnaz, Ghojazadeh Morteza, Asgharzadeh Ali. 2017. Communication Skills of Physicians 
and Patients' Satisfaction. Mater Sociomed. 2017 Sep; 29(3): 192-195. doi: 10.5455/ msm.2017.29.192-195. [Diakses pada tanggal 29 Agustus 2019], tersedia di https://www.ncbi. nlm.nih.gov/pmc/articles/PMC5644191/

11. Arikunto Suharsimi. Prosedur Penelitian : Suatu Pendekatan Praktis, edisi revisi 2010: Jakarta. Rineka Cipta. 2010

12. Dahlan Sopiyudin. Statistika untuk Kedokteran dan Kesehatan. Jakarta. Salemba Medika. 2008

13. Sugiyono. 2013. Metode Penelitian Pendekatan Kuantitatif dan R \& D. Bandung. Alfa Beta.

14. Norouzinia Roohangis, Aghabarari Maryam, Shiri Maryam, Kharimi Mehrdad, Sami Elham. 2016. Communication Barriers Perceived by Nurses and Patients. Glob J Health Sci. 2016 Jun; 8(6): 65-74. [Diaskes pada tanggal 29 Agustus 2019], tersedia di https://www.ncbi. nlm.nih.gov/pmc/articles/PMC4954910/

15. Lidgeet Cary. 2016. Improving the patient experience through a commit to sit service excellence initiative. Patient Experience Journal ; Vol. 3 : Iss. 2 , Article 11. [Diakses pata tanggal 14 September 2019], tersedia di https://pxjournal.org/cgi/viewcontent. cgi? article $=1148 \&$ context $=$ journal

16. Zemguilene Jolanta. Managing Blood Donorship: The Effect of Motivation Donor Satisfaction on Donors Satisfaction and Loyalty. ISSN 2029-9370 (Print), ISSN 2351-6542. Regional Formation and Development Studies, No. 2 (19). [Diakses pada tanggal 16 September 2019], tersedia di http://journals.ku.lt/index. php/RFDS/article/view/1291

17. Chatterjee, S., \& Choudhury, N. 2011. Medical Communication Skills Training in the Indian Setting: Need of the Hour. Asian Journal of Transfusion Science, 5(1), 8. doi:10.4103/09736247.75968. [Diakses 23 September 2019], tersedia di http://www.ajts.org/article. asp?issn $=0973-6247$; year $=2011$; volume $=5$;issu $\mathrm{e}=1$; spage $=8$; epage $=10$; aulast $=$ Chatterjee

18. Waller Daniel, Thijsen Amanda, Garad Allira, Hayman Jane, Smith Geof. 2017. Donating Blood for Research: A Potential Method for Enhancing Customer Satisfaction of Permanently Deferred Blood Donors. Blood Transfuse 2017; 15: 13-9 DOI 10.2450/2015.0142-15. [Diakses pada tanggal 23 September 2019], tersedia di https:// pubmed.ncbi.nlm.nih.gov/26674813/ 